\title{
KEMAMPULABAAN PERUSAHAAN BERDASARKAN EFISIENSI MODAL KERJA, PERTUMBUHAN PENJUALAN, DAN UKURAN PADA PERUSAHAAN "MAKANAN DAN MINUMAN"
}

\author{
(THE COMPANY'S PROFITABILITY BASED ON WORKING CAPITAL \\ EFFICIENCY, SALES GROWTH, AND SIZE OF "FOOD AND BEVERAGES" \\ COMPANY)
}

Oleh:

Estuti Fitri Hartini ${ }^{1)}$; Sopiyatul Badriyah2)

Sekolah Tinggi Ilmu Ekonomi IPWI Jakarta1,2)

estuti16@gmail.com ${ }^{1)}$; sopiyatulbadriyah24@gmail.com ${ }^{2)}$

Submit: 16 Mar $2020 \quad$ Review: 12 Apr 2020 Accept: 24 Apr $2020 \quad$ Publish: 30 Apr 2020

\begin{abstract}
The Profitability of food and beverage manufacturing companies is suspected to be due to the influence of efficiency of working capital, sales growth, even company size. Proof of this need to be carried out research which is the objective in analyzing profitability that is influenced by the efficiency of working capital and growth of sales, as well as company size in the Indonesian food and beverage subsector manufacturing companies in the 2015-2017 period. The research data was taken from www.idx.co.id as many as 15 companies as a sample of 21 populations. A causal study with a quantitative approach, multiple regression as an analysis tool, $t$ test as hypothesis testing. Explanation of results, the efficiency of working capital as a factor influencing profitability; sales growth is not as affecting profitability; company size is not an influence factor of profitability.
\end{abstract}

Keywords:

Profitability, working capital efficiency, sales growth, and company size.

\section{ABSTRAK}

Kemampulabaan perusahaan manufaktur makanan dan minuman diduga atas pengaruh efisiensi dari modal kerja, pertumbuhan penjualan, bahkan ukuran perusahaan perusahaan. Pembuktian hal tersebut perlu dilakukan penelitian yang merupakan tujuan dalam menganalisis kemampulabaan yang dipengaruhi efisiensi dari modal kerja dan pertumbuhan dari penjualan, serta ukuran perusahaan pada perusahaan manufaktur sub sector makanan dan minuman Indonesia periode 2015-2017. Data penelitian diambil dari www.idx.co.id sebanyak 15 perusahaan sebagai sampel dari 21 populasi. Merupakan penelitian kausal dengan pendekatan kuantiatif, regresi berganda sebagai alat analisis, uji t sebagi pengujian hipotesis. Penjelasan hasil, efisiensi dari modal kerja sebagai faktor pemberi pengaruh 
atas kemampulabaan; pertumbuhan penjualan tidak sebagai yang mempengaruhi profitabilitas; ukuran perusahaan bukan merupakan faktor pengaruh dari profitabilitas.

Kata kunci:

Kemampulabaan, efisiensi dari modal kerja, dan pertumbuhan penjualan, serta ukuran perusahaan.

\section{PENDAHULUAN}

Perkembangan dunia bisnis saat ini sangatlah pesat, tujuan utama perusahaan memaksimalkan kekayaan bagi para pemiliknya. Kemampulabaan atau profitabilitas mampu dalam menghasilkan keuntungan. Semakin tinggi perbandingan laba setalah pajak atas total aktiva maka menggambarkan perusahaan dalam kondisi lebih baik. Perusahaan manufaktur dari sub sektor industri makanan dan minuman saat ini mengalami pertumbuhan positif sehingga profit meningkat. hal ini disebabkan karena perusahaan ini dalam kondisi krisispun konsumen akan tetap membutuhkan makanan dan minuman agar tetap memenuhi kebutuhan pokoknya. Dengan demikian perusahaan ini perlu memperhatikan faktor pendukung yang mempengaruhi profitabilitas diantaranya modal kerja yang efisiensi (WCT), pertumbuhan dari penjualan (Sales Growth), dan juga ukuran perusahaan (Firm Size) dalam memantau profitabilitas yang diperoleh perusahaan manufaktur dari sub sektor industri makanan dan minuman.

\section{TUJUAN PENELITIAN}

Melaksanakan analisis faktor yang mempengaruhi kemampulabaan seperti efesiensi dari modal kerja, perubahan penjualan dan ukuran perusahaan.

\section{TELAAH LITERATUR DAN PENGEMBANGAN HIPOTESIS Profitabilitas}

Kemampulabaan digambarkan dalam kemampuan perusahaan menghasilkan keuntungan

(Werner,2013:63). Kemampulabaan yang mampu dihasilkan dalam suatu periode (Barus dan Leliani, 2013). Profitabilitas dapat dilihat pula dari perputaran penjualan (Lalu, dkk:2016). (I Made Sudana,2011:220), pemilihan indikator/parameter Return On Assets (ROA) karena rasio profitabilitas dapat dijadikan alat ukur kemampuan untuk menghasilkan laba dari aset yang digunakan. (Brigham dan Houston,2014:201) ROA merupakan rasio laba bersih terhadap total aktiva setelah bunga dan pajak. Jika suatu perusahaan mempunyai ROA yang tinggi maka perusahaan tersebut berpeluang besar dalam meningkatkan pertumbuhan. (Rifai, dkk:2015) bahwa ROA dapat menunjukkan produktivitas seluruh dana perusahaan. Artinya ROA dapat dijadikan tolak ukur perkembangan perusahaan kedepannya, (Windarti dan EF Hartini:2019). Simpulan dari hal diatas bahwa Profitabilitas menjadi ukuran keberhasilan perusahaan dengan memanfaatkan aktivitas ROA yang efektif. ROA dapat dinyatakan dalam formulasi berikut:

$R O A=\quad \frac{\text { Net Income }}{\text { Total asset }}$


Efisiensi Modal Kerja

Menurut Riyanto (2014) Working Capital Turnover (WCTO) adalah kemampuan dari modal kerja yang berputar dalam suatu jangka siklus kas (cash cycle) dari perusahaan. Berdasarkan paparan tersebut terdapat kesamaan dalam rumus efisiensi dari modal kerja, dimana penulis mengambil indikator efisiensi dari modal kerja menurut Riyanto (2014) dimana perputaran modal kerja menjadi rasio aktivitas yang mengukur hubungan dari penjualan dengan jumlah dari ratarata modal kerja. Periode dari perputaran menunjukkan efisien ataukah tidak penggunaan dalam modal kerja. Semakin cepat modal berputar maka semakin efisien modal kerja (Windarti dan EF Hartini:2019). Perputaran modal kerja sebagai pengukur efektifnya modal kerja (Hery, 2015:218). Efisiensi dari modal kerja perlu direncanakan demi pencapaian profitabilitas (Lalu, dkk:2016). Dari hal tersebut (Wibowo dan Wartini:2012), pengukuran profitabilitas perusahaan dapat dilihat dari efesiensi modal kerja. Simpulan hal tersebut menggambarkan bahwa makin dinamis perputaran modal kerja tentunya modal kerja semakin efisien.

$$
W c t o=\frac{\text { Penjualan }}{\text { Aset Lancar - Hutang Lancar }}
$$

\section{Pertumbuhan Penjualan}

Pertumbuhan penjualan adalah rasio yang menggambarkan prestasi perubahan penjualan dari tahun berjalan ke tahun berjalan berikutnya (Harahap, 2010:309)

Pendapatan dan laba dapat diperoleh dari peningkatan penjualan yang ditunjukkan oleh kemampuan perusahaan.

Perubahan penjualan terindikasi adanya pengaruh yang berlawanan dengan perubahan harga saham. Semakin tinggi tingkat pertumbuhan penjualan akan memerlukan modal kerja dan modal untuk investasi, sehingga harga saham akan turun. Pertumbuhan penjualan merupakan bentuk gambaran kenaikan penjualan tahun ini dibanding tahun lalu, Susilowati. SS (2018). Pertumbuhan penjualan merupakan tolak ukur investasi pertumbuhan masa mendatang (Meidiyustiani:2016). Bukti Pertumbuhan penjualan yaitu dengan meningkatnya permintaan barang, sehingga dapat meningkatkan laba perusahaan (Putra dan Badjra:2015). Perusahaan akan tumbuh lebih baik jika adanya peningkaatan yang konsisten atas aktivitas operasinya (Simarmata:2018). Semakin banyak menjual setiap tahunnya maka pertumbuhan penjualan perusahaan bernilai positif.

\begin{tabular}{|c|c|}
\hline Pertumbuhan & 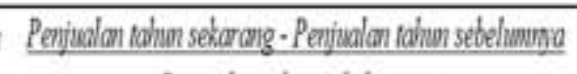 \\
\hline Perijualan = & Penjualan tahen sebelumna \\
\hline
\end{tabular}

\section{Ukuran Perusahaan}

Brigham \& Haouston (2014:4) besar kecilnya perusahaan dapat dilihat dari ukuran perusahaan dan dapat dinili menggunakan total asset, total dari penjualan, jumlah dari laba, beban dari pajak dan sebagainya. Sedangkan menurut Jogiyanto (2007:282) besarnya perusahaan dapat diukur menggunakan besarnya nilai aktiva, nilai aktiva tersebut dapat diukur menggunakan logaritma total aset. Biasanya nilai asset sangat besar, sehingga nilai asset diukur dengan Log Asset atau dapat dipersingkat dengan $\mathrm{Ln}$ dari Total Asset. Peningkatan besarnya total asset menunjukkan besaran nilai perusahaan (Sudarmadji dan Sularto:2007). Profitabilias yang diukur dengan Nilai Perusahaan dapat stabil jika perusahaan dapat mempertahankan ukuran perusahaan (Hartini, EF, dan Widhiastuti, S:2017). Penilaian besar kecilnya perusahaan dilihat besarnya asset (Novyanny. MC dan Turangan. JA:2019). 
Aset merupakan tolak ukur dari ukuran perusahaan. Pemaksimalan asset akan berdampak pada keuntungan perusahaan (Meidiyustiani:2016). Kemampuan dalam mengelola asset dengan baik maka akan terjadi peningkatan ukuran perusahaan.

\section{Ukuran Perusahaan $=\operatorname{Ln}($ Total Aset $)$}

\section{Pengaruh Modal Kerja yang Efisien terhadap Kemampulabaan/Profitabilitas}

Modal kerja yang efisien merupakan perbandingan dari penjualan dengan keseluruhan jumlah aktiva lancar suatu perusahaan dalam kurun periode tertentu. besaran rasio ini dapat menunjukkan betapa efektifnya pemanfaatan dari penggunaan modal kerja yang ada dalam peningkatan profitabilitas perusahaan.

Menurut Riyanto (2014) siklus berputarnya modal kerja dapat dimulai dari awal kas diinvestasikan didalam komponen dari modal kerja hingga saat menjadi kas. Semakin pendek siklus berputarnya modal kerja, artinya modal kerja berputarnya makin cepat, dengan demikian makin tingginya perputaran modal kerja maka perusahaan semakin efisien dan akhirnya menjadi peningkatan profitabilitas. Dukungan dari penelitian sebelumnya telah dilakukan Setiawan (2015) serta Wibowo dan Wartini (2012) bahwa efisiensinya modal kerja memiliki pengaruh terhadap kemampulabaan. Miswanto dkk (2017) juga Meidiyustiani (2016) bahwa signifikansi efisiensinya modal kerja yang diproksikan WTC mempengaruhi profitabilitas. Oleh sebab itu dapat diduga efisiensinya modal kerja mempengaruhi profitabilitas pada perusahaan industri manufaktur makanan dan juga minuman.

H1: Efisiensi dari Modal kerja mempengaruhi profitabilitas.
Pengaruh Pertumbuhan dari Penjualan terhadap Kemampulabaan

Pertumbuhan dari penjualan adalah naik atau turunnya penjualan tahunan dinilai sebagai persentase penjualan (Anatasia et al, 2014:5). Pertumbuhan dari penjualan memiliki nilai pengaruh yang berlawanan dengan harga saham. Tingginya tingkat pertumbuhan penjualan akan memerlukan modal kerja dan modal untuk investasi, sehingga harga saham akan menurun. Penelitian yang juga mendukung hal ini diantaranya Suryaputra, dkk (2016), Chotimah dan Susilowibowo (2014), Novyanny dan Turangan (2019) bahwa perubahan penjualan memiliki pengaruh atas Return On Asset (ROA). Demikian pula Susilowati (2018) kemampulabaan dipengaruhi secara positif dari pertumbuhan penjualan. Menyikapi hal tersebut diduga Pertumbuhan dari penjualan memiliki pengaruh atas Profitabilitas pada perusahaan industri.

H2: Pertumbuhan dari penjualan mempengaruhi profitabilitas.

\section{Pengaruh dari Ukuran Perusahaan atas Profitabilitas}

Ukuran perusahaan dapat digunakan untuk mengukur seberapa besarnya perusahaan, dari ukuran aktiva dapat diukur menggunakan logaritma dari seluruh total aktiva. menurut (Jogiyanto, 2007:282) biasanya nilai aset sangatlah besar, oleh karena itu assets diperkecil menjadi Ln Total Asset atau Logaritma Asset. dukungan penelitian terdahulu ditunjukkan Wirawan, juga oleh Livia Angelia (2017), sama halnya Waseri, dkk (2014), juga Nia Lestianti (2016), sama halnya Miswanto dkk (2017), juga Rifai, dkk (2015), dan Purba dan Yadnya (2015) bahwa profitabilitas dipengaruhi ukuran perusahaan secara positif dan signifikan. Bahkan Meidiyustiani (2016) menunjukkan 
bahwa terindikasi

profiabilitas mempengaruhi ukuran perusahaan signifikan. Oleh sebab itu dugaan ukuran perusahaan mempengaruhi profitabilitas di perusahaan industri sub sektor dari makanan dan minuman.

H3: Ukuran perusahaan mempengaruhi profitabilitas.

\section{Kerangka Penelitian}

Kerangka penelitian berisi pemikiran dalam menjelaskan hubungan variabel bebas (efisiensi dari modal kerja, pertumbuhan dari penjualan serta ukuran perusahaan) dan variabel dependent (profitabilitas) dapat dilihat pada gambar berikut:

Gambar 1

Kerangka Penelitian

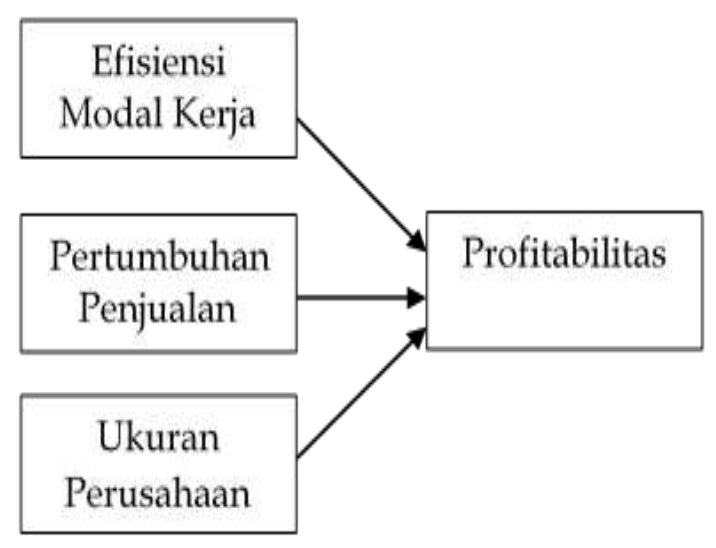

\section{METODE PENELITIAN}

\section{Sampel dalam Penelitian}

Sampel penelitian ini perusahaan industri sub sektor dari makanan dan minuman yang telah terdaftar di BEI pada periode 2015-2017 dan diambil pada www.IDX.co.id yang telah memenuhi semua kriteria penelitian. Sampel diambil memakai teknik, yaitu purposive sampling, teknik memilih sampel yang dapat terpenuhi, diantaranya kelengkapan data.

\section{Desain Penelitian}

Desain penelitian menggunakan pendekatan kuantitatif dan metode explanatory research tipe kasual yang berupaya menguji dari pengaruh variabel bebas terhadap variabel terikat Ahli lain berpendapat bahwa penelitian explanatory merupakan research yang menjelaskan dari hubungan kausal dari variabel research dengan uji hipotesis (Singarimbun dan Effendi; 2003).

\section{Operasionalisasi Variabel}

Berikut Operasionalisasi variabel penelitian dapat dikemukakan sebagai berikut:

\section{Tabel 1}

Operasionalisasi Variabel

\begin{tabular}{|c|c|c|}
\hline Variabel/Konsep & Alat Ukur & Skala \\
\hline $\begin{array}{c}\text { Efisiensi modal kerja }\left(\mathrm{X}_{1}\right) \\
\text { merupakan ketepatan cara } \\
\text { (usaha dan kerja) dalam } \\
\text { menjalankan sesuatu yang } \\
\text { tidak membuang waktu, } \\
\text { tenaga, biaya dan kegunaan } \\
\text { berkaitan penggunaan modal } \\
\text { kerja (Rahma, 2011: 3) }\end{array}$ & $\begin{array}{l}\text { WCTO } \\
\text { (Working } \\
\text { Capital } \\
\text { Turn } \\
\text { Over) }\end{array}$ & Rasio \\
\hline $\begin{array}{l}\text { Pertumbuhan Penjualan }(\mathrm{X} 2), \\
\text { Pertumbuhan penjualan } \\
\text { adalah rasio yang } \\
\text { menggambarkan prestasi } \\
\text { pertumbuhan penjualan dari } \\
\text { tahun ke tahun. } \\
\text { (Harahap,2010: } 309)\end{array}$ & $\begin{array}{l}\text { Persentase } \\
\text { Kenaikan } \\
\text { Penjualan }\end{array}$ & Rasio \\
\hline $\begin{array}{l}\text { Ukuran Perusahaan }(X 3), \\
\text { adalah ukuran besar kecilnya } \\
\text { sebuah perusahaan yang } \\
\text { ditunjukkan atau dinilai oleh } \\
\text { total asset, total penjualan, } \\
\text { jumlah laba, beban pajak dan } \\
\text { lain-lain. Brigham \& } \\
\text { Haouston (2014: } 4)\end{array}$ & $\begin{array}{l}\text { Logaritma } \\
\text { Total Asset }\end{array}$ & Rasio \\
\hline $\begin{array}{c}\text { Profitabilitasn }(\mathrm{Y}), \text { adalah } \\
\text { kemampuan perusahaan } \\
\text { dalam menghasilkan } \\
\text { keuntungan } \\
\text { (Werner,2013:63). }\end{array}$ & $\begin{array}{c}\text { ROA } \\
\text { (Return on } \\
\text { Asset) }\end{array}$ & Rasio \\
\hline
\end{tabular}

\section{Metode Analisis}

Uji data menggunakan uji asumsi klasik normalitas dengan analisis kolmogorov-smirnov yang memiliki tujuan dalam menguji apakah variabel pengganggu atau residual terdistribusi normal dalam model regresi, (Ghozali, 2016). Dilanjutkan dengan analisis regresi 
berganda untuk mencari tahu bagaimana hubungan tiga variabel atau lebih atau sub dari variabel, positif/negatif dan bagaimanakah signifikansi bahkan seberapakah kuat hubungan antara kedua variabel. Nilai kebaikan model menggunakan Adjusted $R^{2}$ tujuannya adalah mengukur dari kemampuan model didalam menerangkan variabel terikat dan Uji kebaikan model menggunakan uji $\mathrm{F}$ yang tujuannya dalam memprediksi dari variabel independen.

Adapun persamaan regresi sebagai berikut:

$$
\mathrm{Y}=\mathrm{a}+\mathrm{b} 1 \mathrm{X} 1+\mathrm{b} 2 \mathrm{X} 2+\mathrm{b} 3 \mathrm{X} 3
$$

Selanjutnya dilakukan uji hipotesis dengan uji t.

\section{HASIL DARI PENELITIAN DAN PEMBAHASANNYA \\ Hasil Penelitian}

Deskripsi berdasarkan hasil dari analisis, sebagai berikut:

Tabel 2

\begin{tabular}{|c|c|c|c|}
\hline \multicolumn{4}{|c|}{ Descriptive Statistics } \\
\hline & Mean & Std. Deviation & N \\
\hline Profftabilitas & 1.08 & 330 & \\
\hline Efisierai Modal Kera & 2.66 & .787 & \\
\hline Pentumbuhan Ponjuaian & 1.11 & .501 & a \\
\hline Ukurm Porvsahasen & 1.63 & .022 & . \\
\hline
\end{tabular}

Deskripsi data bahwa profitabilitas menunjukkan rata-rata sebesar 1,08, standar deviasinya sebesar 0,330. Nilai mean jauh lebih besar dibandingkan standar deviasi yaitu 1,08>0,330. Efisiensi dari modal kerja menunjukkan mean dengan nilai 2,66, standar deviasinya sebesar 0,787. Mean lebih besar dari standar deviasi 2,66>0,787. Pertumbuhan dari penjualan dengan rata-rata nilai 1,11 dan standar deviasinya senilai 0,501 . Mean jauh lebih besar dibandingkan standar deviasi 1,11>0,501. Ukuran dari perusahaan memiliki nilai rata-rata sebesar
1,63, nilai standar deviasi dengan nilai 0,022 . Mean lebih besar daripada standar deviasi yaitu 1,63>0,022.

Tabel 3

One-Sample Kolmogorov-Smimov Test

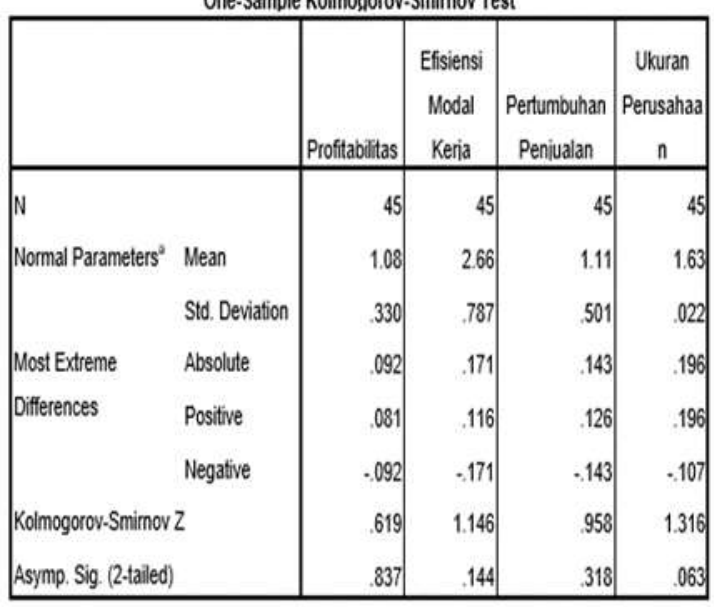

Berdasarkan table diatas, bahwa seluruh variabel besar signifikannya berada diatas 0,05 atau 5\%. Profitabilitas nilai Asymp.sig 0,837 > 0,05, efisiensi modal kerja 0,144 $>0,05$, pertumbuhan penjualan $0,318>0,05$ dan ukuran perusahaan 0,063 > 0,05. Kesimpulan bahwa syarat dari analisis terpenuhi, data berdistribusi normal.

Hasil dari analisis terdapat pada berikut:

Tabel 4

Coefficients²

\begin{tabular}{|c|c|c|c|c|c|c|}
\hline \multicolumn{7}{|c|}{ Coefficients ${ }^{2}$} \\
\hline \multirow{2}{*}{\multicolumn{2}{|c|}{ Model }} & \multicolumn{2}{|c|}{$\begin{array}{c}\text { Unstandardized } \\
\text { Coefficients }\end{array}$} & \multirow{2}{*}{\begin{tabular}{|c|}
$\begin{array}{c}\text { Standardize } \\
d \\
\text { Coefficients }\end{array}$ \\
Beta \\
\end{tabular}} & \multirow[b]{2}{*}{$t$} & \multirow[b]{2}{*}{ Sig. } \\
\hline & & B & $\begin{array}{l}\text { Std. } \\
\text { Error }\end{array}$ & & & \\
\hline \multirow[t]{4}{*}{1} & (Constant) & -993 & 3.523 & & -.282 & 779 \\
\hline & Efisiensi M odal Kerja & .168 & .059 &. .402 & 2.877 & .006 \\
\hline & Pertumbuhan Penjualan & -.082 & .095 & -.125 & -.866 & .391 \\
\hline & Ukuran Perusahaan & 1.601 & 2.136 & .108 & .749 & .458 \\
\hline
\end{tabular}
nilai:

Hasil persamaan regresi menunjukkan $Y=-0,993-0,168 X 1-0,082 X 2+1,601 X 3$

- Efisiensi dari modal kerja memiliki nilai negatif terhadap profitabilitas, sebesar $b 1=-0,168$; 
- Pertumbuhan penjualan memiliki nilai negative terhadap profitabilitas, sebesar $b 2=-0,082$;

- Ukuran dari perusahaan mempengaruhi Profitabilitas secara positif, sebesar $b 3=1,601$

\section{Pengujian Hipotesis}

Nilai kebaikan model $14,7 \%$, variasi profitabilitas dijelaskan oleh efisiensi dari modal kerja, pertumbuhan dari penjualan juga ukuran perusahaan. Model dari penelitian ini dinyatakan layak untuk diterima oleh karena nilai $\mathrm{F}$ sig. $0.023<$ probabilitas $\mathrm{a}=0,05$.

- Efisiensi dari modal kerja secara signifikan mempengaruhi profitabilitas, $t$ sig. sebesar 0,006 yang lebih kecil dari probabilitas $\alpha=0,05$.

- Pertumbuhan dari penjualan tidak mempengaruhi profitabilitas, $\mathrm{t}$ sig. sebesar 0,391 yang lebih besar dari probabilitas $\mathrm{a}=0,05$.

- Ukuran perusahaan juga tidak mempengaruhi profitabilitas, $\mathrm{t}$ sig. sebesar 0,458 yang lebih besar dari probabilitas $\mathrm{a}=0,05$.

\section{Pembahasan}

Pengaruh efisiensi dari modal kerja terhadap kemampulabaan/profitabilitas perusahaan

Hasil penelitian dapat ditujukkan bahwa profitabilitas dipengaruhi efesiensi modal kerja, konsisten terhadap penelitian Miswanto dkk (2017), Meidiyustiani (2016), Setiawan (2015) serta Wibowo dan Wartini (2012), mereka menyimpulkan dari penelitiannya yang mana kemampulabaan atau profitabilitas mempengaruhi efesiensi dari modal kerja, artinya besar atau kecilnya profitabilitas dari perusahaan efisiensi dari modal kerja yang mempengaruhinya.

Penelitian ini didukung teori yang dikemukakan oleh Riyanto (2014) efisiensi dari modal kerja akan dapat dilihat dalam perputaran dari modal kerja atau yang sering dikatakan WCT dapat menggunakan perhitungan rasio total penjualan dengan jumlah modal kerja ratarata. Perputaran dari modal kerja dimulai diinvestasikannya kas didalam komponenkomponen modal kerja hingga saat berputar menjadi kas. Makin pendeknya periode dalam perputarannya modal kerja, aartinya makin cepat perputarannya hingga perputaran modal kerjanya makin meningkat/tinggi dan tentu perusahaan makin memperoleh efisien sehingga peningkatan profitabilitas juga tinggi.

\section{Pengaruh dari pertumbuhan penjualan terhadap kemampulabaab/profitabilitas perusahaan}

Pertumbuhan dari penjualan tidak terlihat mempengaruhi profitabilitas, artinya jika pertumbuhan dari penjualan yang mengalami kenaikan tentu tidak memberi dampak yang mempengaruhi profitabilitas.

Penelitian ini dinyatakan tidak ada kekonsistenan dengan beberapa peneliti diantaranya Turangan (2019), juga penelitian Susilowati (2018), sama halnya dengan Suryaputra, dkk (2016), begitu pula Chotimah dan Joni Susilowibowo (2014), serta menurut Novyanny dan bahwa nilai pertumbuhan dari penjualan berpengaruh atas Return On Asset (ROA). Namun ada kekonsistenan atas penelitian Miswanto dkk (2017) dan juga Lestianti (2015) bahwa pertumbuhan dari penjualan tidak ada pengaruhnya atas profitabilitas. Hasil dari ini telah menunjukkan bahwa pertumbuhan dari penjualan tentu disertai dengan beberapa peningkatan biaya dan penambahan dari aktiva yang lebih besar, hingga profitabilitas yang lebih diharapkan tercapai tidak terjadi. 


\section{Pengaruh dari ukuran perusahaan terhadap kemampulabaan/profitabilitas perusahaan}

Hasil dari penelitian yang ditunjukkan, bahwa diakui ukuran perusahaan tidak memberikan pengaruh atas profitabilitas, yang diartikan profitabilitas tidak terdampak meskipun ukuran perusahaan semakin besar.

Bahkan hal ini tidaklah sejalan dengan beberapa penelitian dibeberapa periode lalu diantaranya Wirawan, juga yang dilakukan Livia Angelia (2017), dilakukan Miswanto dkk (2017), termasuk Nia Lestianti (2016), bahkan Rifai, dkk (2015), Purba dan Yadnya (2015) dan Waseri, dkk (2014), kesimpulan mereka ukuran perusahaan terindikasi pengaruh atas profitabilitas dengan positif. Penelitian yang dapat dinyatakan sejalan adalah dengan penelitian salah seorang yaitu Meidiyustiani (2016) ukuran perusahaan tidak ada berpengaruh terhadap kemampulabaan/profitabilitas. Penelitian inipun dapat dukungan dari teori yang dijelaskan Sari dan Budiasih (2014) bahwa tidak menjamin ukuran perusahaan mampu sebagai penghasil laba yang baik. Semakin besarnya ukuran dari suatu perusahaan dalam menjalankan operasional, biaya yang dibutuhkan perusahaan tersebutpun jauh lebih besar hingga profitabilitas akan berkurang oleh karenanya. Maka total asset tidak suatu keharusan dapat sebagai pengukur profitabilitas.

\section{KESIMPULAN}

a. Efisiensi dari modal kerja memberikan dampak. terhadap kemampulabaan/profitabilitas.

b. Pertumbuhan penjualan tidak ada dampaknya terhadap profitabilitas perusahaan. c. Profitabilitas tidak terdampak atas ukuran perusahaan.

\section{SARAN}

a. Penambahan variable bagi yang akan menjadi peneliti berikutnya menjadi suatu keharusan untuk memaksimalkan penelitian.

b. Penilaian jangka panjang perusahaan atas penelitian ini belum dapat dicerminkan karena penelitian terlalu singkat.

\section{DAFTAR PUSTAKA}

Adreani Caroline Barus, Leliani. 2013. "Analisis Faktor-Faktor yang mempengaruhi profitabilitas pada Perusahaan Manufaktur yang Terdaftar di Bursa Efek Indonesia". Jurnal Wira Mikrosil. (volume 3 Nomor 02:112).

Brigham \& Houston. 2014. Dasar-Dasar Manajemen Keuangan. Jakarta: Salemba Empat.

Chotimah, Joni Susilowibowo. 2014. "Pengaruh Struktur Modal, Modal Kerja dan Pertumbuhan Penjualan Terhadap Profitabilitas". Jurnal IImu Manajemen, Volume 2 Nomor 2 April 2014.

Ghozali, Imam. 2016. Aplikasi Analisis Multivariate Dengan Program IBM SPSS 23 (Edisi 8). Cetakan KE VIII. Semarang: Badan Penerbit Universitas Diponegoro.

Harahap, Sofyan Syafri. 2010. Analisis Kritis atas Laporan Kevangan. Jakarta: Rajawali Persada.

Hartono, Jogiyanto. 2007. Portofolio dan Analisis Investasi. BPFE. Yogyakarta.

Hartini. EF, Widhiastuti.S. 2017. "Pengaruh Struktur Modal, Ukuran Perusahaan, Modal Kerja Terhadap Kinerja Perusahaan dan Dampaknya Terhadap Nilai Perusahaan", Jurnal Manajemen dan Kewirausahaan, Vol.14, No.02-desember 2017, 
http://ejurnal.stieipwija.ac.id/index.p hp/jmk/article/view/61

Hery. 2015. Analisis Laporan Kevangan, Cetakan Pertama, Yogyakarta.

Lalu R.S., Saerang I.S., Murni S., 2016 "Analisis Efisiensi Penggunaan Modal Kerja pada Perusahaan Semen Yang Tercatat di BEl Periode 2010-2014", Jurnal EMBA, Vol.4, No.5 September 2016, Hal.303-408, ISSN 2303-1174.

Lestianti, Nia. 2016. "Pengaruh Efisiensi Modal Kerja, Pertumbuhan Penjualan, dan Ukuran Perusahaan Terhadap Profitabilitas". Skripsi. Universitas Negeri Yogyakarta.

Meidiyustiani. Rinny. 2016. "Pengaruh Modal Kerja, Ukuran Perusahaan, Pertumbuhan Penjualan danLikuiditas Terhadap Profitabilitas Pada Perusahaan Manufaktur Sektor Industri Barang Konsumsi Yang Terdaftar Di Bursa Efek Indonesia (BEI) Periode 2010-2014", Jurnal Akuntansi dan Keuangan, Vol.5, No.2, Oktober 2016, ISSN:2252-7141.

Miswanto dkk. 2017. "Pengaruh Efisiensi Modal Kerja, Pertumbuuhan Penjualan dan Ukuran Perusahaan Terhadap Profitabilitas Perusahaan", Jurnal Bisnis dan Ekonomi (JBE), Vol.24, No.2, Hal.119-135, September 2017, ISSN:1412-3126.

Novyanny. MC dan Turangan. JA. 2019. "Pengaruh Likuiditas, Ukuran Perusahaan, Umur Perusahaan dan Pertumbuhan Perusahaan Terhadap Profitabilitas Pada Perusahaan Jasa Sektor Perdagangan, jasa \& Investasi Yang Terdaftar Pada Bursa Efek Indonesia", Jurnal Manajemen dan Kewirausahaan, Vol.1, No.1, 2019.

Purba, IBGIW dan Yadnya P.2015. "Pengaruh Ukuran Perusahaan dan Leverage Terhadap Profitabilitas dan Pengungkapan Corporate Social Responsibility". E-Jurnal E-Jurnal Manajemen Universitas Udayana, Vol.4, No.8, 2015:2428-2443: ISSN:2302-8912.

Putra AAWY dan Badjra IB. 2015. "Pengaruh Leverage, Pertumbuhan Penjualan, dan Ukuran Perusahaan Terhadap
Profitabilitas". Jurnal. E-Jurnal Manajemen Universitas Udayana, Vol.4, No.7, 2015:2052-2067: ISSN:2302-8912.

Rahma, Aulia. 2011. "Analisis Pengaruh Modal Kerja Terhadap Profitabilitas Pada Perusahaan Manufaktur PMA dan PMDN di BEl, Skripsi, Sarjana Fakultas Ekonomika, Universitas Diponegoro".

Eprint.undip.ac.id/28981/1/Skripsi017. pdf

Rifai, M, dkk. 2015 "Pengaruh Ukuran Perusahaan, Struktur Modal dan Pertumbuhan Perusahaan Terhadap Profitabilitas Studi Pada Perusahaan Manufaktur di BEl Tahun 2010-2012", Jurnal IImiah Mahasiswa SI Akuntansi Universitas Pandanaran, ISSN 25027697, Vol.1 No.1 Februari 2015.

Sari, Ni Made Vironika dan Budiasih, I.G.A.N. 2014. "Pengaruh Debt to Equity Ratio, Firm Size, Inventory Turnover dan Assets Turnover pada Profitabilitas". EJurnal Akuntansi Universitas Udayana, 6 (2), h: 261-273.

Setiawan, Wawan. 2015. "Pengaruh Efisiensi Modal Kerja dan Likuiditas Terhadap Profitabilitas". Skripsi. Universitas Maritim Raja Ali Haji.

Simarmata, Ivanna. 2018. "Pengaruh Tingkat Pertumbuhan Penjualan dan Struktur Modal Terhadap Profitabilitas Pada Perusahaan Makanan dan Minuman Yang Terdaftar di Bursa Efek Indonesia". JOM FISIP, Vol.5, Edisi II, Juli-Desember 2018.

Singarimbun, Masri dan Sofian Effendi. 2003. Metode Penelitian Survei. Jakarta: LP3ES

Sudana, I Made. 2011. Manajemen Keuangan Perusahaan. Erlangga, Jakarta.

Sudarmadji AM dan Sularto, Lana. 2017. "Pengaruh Ukuran Perusahaan, Profitabilitas, Leverage, dan Kepemilikan Perusahaan Terhadap Luas Voluntary Disclosure Laporan Keuangan Tahunan". Proceeding PESAT, Vol.2.

Suryaputra dan Yulius Jogi Christiawan. 2016. "Pengaruh Manajemen Modal 
Kerja, Pertumbuhan Penjualan dan Ukuran Perusahaan Terhadap Profitabilitas". Jurnal Business Accounting Review, Vol.4, No.1 (2016).

Susilowati. SS. 2018, "Analisis Pertumbuhan Penjualan dan Perputaran Modal Kerja Terhadap Profitabilitas PT. Tiga Pilar Sejahtera Food, Tbk Tahun 20122016", Akuntabilitas: Jurnal Ilmu Akuntansi, Volume 11 (1), 2018:147158, P-ISSN:1979-858X, E-ISSN:24611190, DOI:10.15408/akt. v1 1i1. 7180.

Waseri, dkk. 2014. "Pengaruh Tingkat Perputaran Modal Kerja, Struktur Modal dan Ukuran Perusahaan Terhadap Profitabilitas Pada Perusahaan Whole Sale and Retail Trade di Bursa Efek Indonesia Periode 2008-2011", JOM FEKON, Vol.1 No.2 Oktober 2014, Universitas Pekanbaru.

Werner R Murhadi. 2013. Analisis Laporan Kevangan Lanjutan Proyeksi dan Valuasi saham. Jakarta: Salemba Empat.

Wibowo dan Sri Wartini. 2012. "Efisiensi modal kerja, Likuiditas dan Leverage
Terhadap Profitabilitas". Jurnal Dinamika Manajemen (JDM), Vol.3, No.1 (2012), ISSN 2086-0668; ISSN 23375434

Windarti dan EF Hartini. 2019. "Pengaruh Modal Kerja, Perputaran Modal Kerja dan Skala Perusahaan Terhadap Profitabilitas Perusahaan Otomotif di Indonesia", Jurnal Pengembangan Wiraswasta,

http://ejurnal.stieipwija.ac.id/index.p hp/jpw DOI:http://dx.doi.org/10.33370/jpw.v 21i3.341; p-ISSN 1411-710x; e-ISSN 2620-388x

Wirawan, Livia Angelia. 2017. "Pengaruh Ukuran Perusahaan, Solvabilitas, Likuiditas dan Perputaran Modal Kerja Terhadap Profitabilitas". Skripsi, http://repositori.usu.ac.id/handle/12 3456789/858. Universitas Sumatera Utara.

WWW.IDX.co.id 